\title{
Still Located at the Gingerbread House, 1981
}

The dead mocked me because I didn't fit in. And the dead of other species could not protest. At best, a tree-death, given four legs, held our bowls and, in useless times, looked pretty in a fading light.

So I left stone, those colors in a hard embrace. I shed the wind dying to a gasp.

I came instead to apples, smell and taste holding me like two hands. Stone returned, called by a fruit-stirred vision.

Wind held me as though I'd give it more breath.

Mineral and muttering, I still would not face an old childhood that blamed sweet wildness. We spent our years learning the petty so we could be grown-up, another form of death.

What sparks escaped the powers, I now breathe to an uneasy life. Hearing a bird-song gives me the idea to sing, and if I don't get the bird-song right, my mistake counts as another song. When I catch a cold, love calls my voice smoky. The near-dead take these crumbs like birds that, in hunger, wipe clean the trail leading out of the woods. 